\title{
IMPROVING IRRIGATION WATER CONVEYANCE AND DISTRIBUTION EFFICIENCY USING LINED CANALS AND BURIED PIPES UNDER EGYPTIAN CONDITION
}

\author{
E. A. M. Osman" ; G. A. Bakeer ${ }^{* * *}$; M. E. Abuarab ${ }^{* * * *}$ and \\ M. T. Eltantawy ${ }^{* * * *}$
}

\section{ABSTRACT}

A field experiment was carried out at El-Mahmoudia command area at El-Beheira governorate, Egypt, during two growing seasons summer and winter 2014/2015, to Improve irrigation water conveyance efficiency using lined canal and upvc buried pipes under Egyptian conditions. The experiment consists of three types of on-field water distribution canals (Merwas); Earthen canal, Lined canal and Upvc buried pipes. Six Evaluation parameters were measured; conveyance efficiency, water saving, irrigation time, land saving, cropping intensity and crop yield, the financial analysis had been applied. The result showed that the conveyance efficiencies were $65 \%, 9 r .2 \%$ and $98.7 \%$ in winter, while the conveyance efficiencies were 59.6\%, $87.1 \%$ and $91.7 \%$ in summer, for earthen canal, lined canal and buried pipes, respectively. The impact of development on reducing conveyance losses comparing with earthen canal were $68.1 \%$ and 96.3 for summer, while it was $77.7 \%$ and 96.3 for winter, under lined canal and upvc buried pipes, respectively. The impact of improvement on decreasing irrigation time was ranged from $50 \%$ to $60 \%$ for the different field crops. The benefits of land saving were about $0.8 \%$ of the total saved area after development by lined canal and $1.4 \%$ of the total command area saved after development by upvc buried pipes, it had become available for agriculture. The highest profit as a percent was obtained under maize, for both lined canal and buried pipes, respectively.

Keywords: Conveyance efficiency, earthen canal, lined canal, buried pipes.

\footnotetext{
* B.Sc. Agric. Sci. (Soil Science) - Faculty of Agricultural - Cairo University.

** Professor of Agriculture Engineering - Faculty of Agricultural - Cairo University.

*** Associate Professor of Agricultural Engineering - Faculty of Agric. - Cairo University. **** Head Research of Agriculture Engineering - Institute of Agriculture Engineering Research.
} 


\section{INTRODUCTION}

$\mathrm{E}$ gypt is characterized as arid climate with very limited rainfall. The vast majority of the country is desert land, and crop production is virtually fully dependent on irrigation. Egypt gets more than $95 \%$ of its annual renewable water resources from the Nile. Egypt may face significant water scarcity within the foreseeable future, however, because of the combination of a more or less fixed supply of fresh water and increasing demands for water owing to population growth and reclamation of desert land for agricultural production. The major water user in the Egyptian economy agriculture is the largest user of water consuming $86.5 \%$ of the total water amount used, compared to $5.8 \%$ and $7.7 \%$ for municipal and industrial uses, respectively FAO Aquastat, (2008).

Ibrahim, (2003). in the traditional irrigation system in the old lands, water is delivered to farmers on a rotational basis, which is normally applied at the branch canals. This system has some disadvantages such as; severe shortage of water at the tail reaches; low conveyance efficiency; high operational cost; and excessive water loss to drains. Tremendous efforts should be implemented towards effective management for irrigation system

Hvidt (1998), have shown that farmers have applied $50 \%$ to $250 \%$ more water than required by the crops and for the purpose of leaching.

According to Ali (2011), the conveyance efficiency in irrigation projects is poor due to seepage, percolation, cracking and damaging of the earth channel. Seepage losses in irrigation water conveyance system are very significant, as it forms the major portion of the water loss in the irrigation system the geometric factors involved in the estimation of the seepage are the shape and dimensions of the irrigation channel and the depth of the water table and the depth to an impervious layer. Anonymous, (2014).the conveyance efficiency in the unlined irrigation system, which is about 56 $\%$, can be increased to $88 \%$, when the whole system is lined. Therefore, there is considerable scope of improving the efficiency of water use by lining the system Rahman et al. (2011), revealed that average conveyance efficiency of UPVC buried pipe ranged from $94.46 \%$ to $95.37 \%$ and rate of water loss ranged from $5.45 \%$ to 9.55 per cent. The 
conveyance efficiency of pipe flow increased up to $95 \%$.Arshad and Ahmad (2011), lining has increased 25\% conveyance efficiency and if we lined all other watercourses not only conveyance efficiency will be improved but will also help in equal water distribution among farmers and will increase the command area of that watercourse.Sayed.,(2014). found that conveyance losses were to be $41 \%, 48 \%$ and $45 \%$ in existing earthen canals at Mithapukur, Manikganj Sadar and Dhamrai respectively. The reducing of canal losses would improve the efficiency of the irrigation systems and, consequently, it would reduce also the amount of water diverted for irrigation.

Akbar et al. (2013), said that reducing canal losses would improve the efficiency of the irrigation systems and, consequently, it would reduce also the amount of water diverted for irrigation. Sahu et al., (2014). Some of the most important tangible benefits resulting from lining irrigation canals those that can be evaluated with some accuracy are water saving that would otherwise be lost though seepage, reclamation of water logged lands, lower maintenance and economies of canal lining operational cost. Memon, et al., (2013). Lining provides flatter hydraulic gradient or bed slope, prevents silting of channels, makes bankers stable, acts anti-water logging measure as it reduces seepage to the adjoining land and it also reduces weed growth and increases stability of section. Schwab et al., (1993).Pipeline delivery systems eliminate almost all the conveyance losses expected under open channel delivery systems. Low pressure buried pipe distribution systems for surface irrigation constitute evaluable alternative to open channel distributors. Maniruzzaman et al. (2002), reported that the conveyances loss was 2.8 to $9.5 \%$ in PVC and plastic pipe whereas in earthen channel it varied from 30 to $33 \%$ in silty-clay loam soil. Kotb and Boissevain (2013), conducted a field study and confirmed the figures of $2 \%$ land savings, conveyance efficiency of $98 \%$, reduction in irrigation time of 50-60\%, 5-30\% increase in crop yields and added that overall water savings of $10 \%$ in summer and $5 \%$ in winter were achieved since the implementation of the Irrigation Improvement Project (IIP).

INCID, (1998). the advantages of low pressure buried pipe operation, maintenance and management of the off farm systems are easier and less 
costly than that of surface distributors. Under the environmental perspective, advantages relate to reduced water losses, more efficient use of agricultural land, reduced damage of land through waterlogging and salinity, reduced damage of water resources, greater transit efficiency, control of aquatic weeds and associated pests. But the disadvantages are investment costs generally higher. Javaid, et al. (2012), said that lining is a long term effective technique for reducing seepage losses from watercourses but it is a highly cost intensive, in addition the lining improvement provides a smooth surface, the sagacity coefficient decreases as the resistance to flow decreases and hence velocity of flow increases. El-Kassar, (2007). Irrigation water is generally delivered below field level each farmer simply pumps irrigation water from the open mesas using a pump that the farmer either owns himself or hires when he wants to irrigate, and thus farmers incur pumping costs when irrigating but over time low-cost powered pumps have become available.The replacement of individual pumping units with a centrally operated pumping system, which managed by the users themselves through water user associations, improves irrigation efficiency. The shift from individual to collective pumping has reduced operational costs by onethird.

Therefore, the main objectives of this study were achieve a good irrigation management by increasing conveyance and distribution efficiencies, decrease water losses due to poor existing canals and decreasing operating energy by using upvc buried pipes.

\section{MATERIALS AND METHODS}

Evaluation was carried out at El-Mahmoudia command area, Kafr El-Dawar, El-Beheira Governorate Egypt. which Located in the northern part of the country in the Nile delta its coordinates $30.61^{\circ} \mathrm{N}, 30.43^{\circ} \mathrm{E}$, ElMahmoudia canal off-takes from Rosetta branch at $194.2 \mathrm{~km}$.

\subsection{Experimental locations}

2.1.1. Abdel-Mawgoud station The station located on left band for Abees El-gadeda branch canal, which service 73fed. the Measurements were carried out to 3 Merwas UPVC buried pipe 4 bar operating pressure, 
$250 \mathrm{~mm}$ diameter and water point 6/fed a description of Abd EIMawgoud pumping station and measuring points are shown in Table (1) and (2).

2.1.2. Om El-laben station the station located at om El-Laban station ElMesqa El-Baharia on the right band for El-Qenawya branch canal which service 149 fed and 8 carats, the Measurements were carried out at 3 rectangular open concrete-lined canal dimensions of bases $(90 \mathrm{~cm}$ width $\mathrm{x}$ $8 \mathrm{~cm}$ thickness), sides from red blocks (40 $\mathrm{cm}$ height, Cover the sides in and out by cement and sand the canal dimensions (40 x 40 x 40cm) (Table 3 and 4).

2.1.3. Bloktor district located on the right band for small branch canal Gnnabyt Zohra (2 km length and 700 fed served area). Off-takes from ElMahmoudia main canal the measurements points on 3 unlined Merwas which take the water from branch canal directly by the private farmer's pumps table (5) description of 3 Merwas

\subsection{Evaluating parameters}

2.2.1. Determination of conveyance efficiency Water conveyance efficiency $\left(E_{C}\right)$ is the ratio in percent of the amount of water delivered by a channel or pipeline to the amount of water delivered to the conveyance system. Conveyance efficiency $\left(\mathrm{E}_{\mathrm{C}}\right)$ was computed with the adoption of the following formula (James, 1988):

$\mathrm{E}_{\mathrm{C}}=\left(\mathrm{Q}_{\mathrm{o}} / \mathrm{Q}_{\mathrm{i}}\right) * 100$

Where:

$\mathrm{E}_{\mathrm{C}}$ : conveyance efficiency in percent,

$\mathrm{Q}_{0}$ : quantity of water delivered by a conveyance system (outflow)

$\mathrm{Q}_{\mathrm{i}}$ : quantity of water delivered to a conveyance system (inflow)

\subsubsection{Unlined open canal}

There are several methods of measuring flow in open irrigation channels on the farm. The velocity-area method was adopted to measure the rate of 
flow in three earthen canals. The rate of flow passing a point in an open channel was measured by multiplying the cross-sectional area of the flow section at right angles to the direction of flow by the average velocity of water.

$\mathrm{Q}=\mathrm{A} * \mathrm{~V}$

Where,

$\mathrm{Q}=$ discharge rate $\left(\mathrm{m}^{3} / \mathrm{s}\right)$

$\mathrm{A}=$ area of cross-section of canal $\left(\mathrm{m}^{2}\right)$

$\mathrm{V}=$ average velocity of flow $(\mathrm{m} / \mathrm{s})$

The cross-sectional area was determined by direct measurements. The velocity was measured by float method. A straight section of channel about $30 \mathrm{~m}$ long with fairly uniform cross-section was selected. Several measurements of depth and width were made within the trial section to arrive at the average cross sectional area. To determine the velocity of surface water of the channel, the length of trail section was divided by the average time taken by the float to go through the $30 \mathrm{~m}$ section. Since the velocity of the float on the surface of the water will be greater than the average velocity of the stream, it was necessary to correct the measurement by multiplying by a constant factor (velocity correction factor) which is usually assumed to be 0.66 according to (James, 1988). To obtain the rate of flow, this average velocity (measured velocity* correction factor) was multiplied by the average cross-sectional area of the stream.

Table 5. The description of measurements points on 3 Merwas.

\begin{tabular}{lll}
\hline Merwa type & $\begin{array}{l}\text { Serviced area } \\
(\mathbf{f e d})\end{array}$ & $\begin{array}{l}\text { Merwa length } \\
(\mathbf{m})\end{array}$ \\
\hline unlined & 4 & 200 \\
unlined & 6 & 250 \\
unlined & 6 & 350 \\
\hline
\end{tabular}


Table 1. Description of the Abees pumping station.

\begin{tabular}{|c|c|c|c|c|c|c|c|c|c|}
\hline Pump Type & $\begin{array}{l}\text { Power } \\
\text { source }\end{array}$ & & $\begin{array}{l}\text { Pun } \\
\text { (m) }\end{array}$ & ap head & r.p.m & $\begin{array}{l}\text { Motor hors } \\
\text { power }(\text { HP) }\end{array}$ & $\begin{array}{l}Q \\
\left(\mathrm{~m}^{3} h^{-1}\right)\end{array}$ & $\begin{array}{l}\text { Number of } \\
\text { pumps }\end{array}$ & $\begin{array}{l}\text { Installation } \\
\text { date }\end{array}$ \\
\hline Centrifugal & Electricity & & 13 & & 1470 & 10 & 110 & 3 & 2012 \\
\hline \multicolumn{10}{|c|}{ Table 2. The description of measurements points on 3 Merwas. } \\
\hline $\begin{array}{ll}\text { No. } & \text { of } \\
\text { Merwas } & \end{array}$ & $\begin{array}{l}\text { No. of } \\
\text { outlets }\end{array}$ & $\begin{array}{l}\text { No. } \\
\text { valves }\end{array}$ & & $\begin{array}{l}\text { Serviced } \\
\text { area (fed) }\end{array}$ & Outlet & $\begin{array}{l}\begin{array}{l}\text { Outlet } \\
\text { diameter } \\
(\mathbf{m m})\end{array} \\
\end{array}$ & $\begin{array}{l}\text { Marwa } \\
\text { length (m) }\end{array}$ & $\begin{array}{l}\text { Merwa } \\
\text { pipe type }\end{array}$ & $\begin{array}{l}\text { Distance from } \\
\text { pumping } \\
\text { station }(\mathrm{m})\end{array}$ \\
\hline 1 & 12 & 1 & & 8 & Hydrant & 160 & 250 & UP.V.C. & 20 \\
\hline 2 & 9 & 16 & & 6 & Hydrant & 160 & 241 & UP.V.C. & 778 \\
\hline 3 & 4 & 9 & & 4.5 & Hydrant & 160 & 148 & UP.V.C. & 1011 \\
\hline
\end{tabular}

Table 3. Description of the Om El-Laben pumping station.

\begin{tabular}{|c|c|c|c|c|c|c|c|c|}
\hline \multirow{2}{*}{ Installation date } & \multicolumn{2}{|c|}{ Power source } & \multicolumn{2}{|c|}{ Pump head (m) } & \multicolumn{2}{|c|}{$\mathbf{Q}\left(\mathbf{m}^{3} \mathbf{h}^{-1}\right)$} & \multirow{2}{*}{$\begin{array}{l}\text { No. of } \\
\text { pumps }\end{array}$} & \multirow{2}{*}{ Pump Type } \\
\hline & Elec. & diesel & Elec. & diesel & Elec. & diesel & & \\
\hline 2004 & 2 & 1 & 11 & 10 & 220 & 220 & 3 & Centrifugal \\
\hline
\end{tabular}

Table 4. The description of measurements points on 3 Merwas.

\begin{tabular}{lllllll}
\hline $\begin{array}{l}\text { Marwa } \\
\text { number }\end{array}$ & No. of outlets & $\begin{array}{l}\text { Outlet } \\
\text { Type }\end{array}$ & $\begin{array}{l}\text { Serviced } \\
\text { (fed) }\end{array}$ & $\begin{array}{l}\text { area } \\
\text { length }(\mathbf{m})\end{array}$ & $\begin{array}{l}\text { Space from pumping } \\
\text { station (m) }\end{array}$ & Merwa type \\
\hline 1 & 9 & Gate $40 \mathrm{~cm}$ & 9 & 821 & 70 & lined \\
2 & 3 & Gate $40 \mathrm{~cm}$ & 4 & 200 & 150 & lined \\
3 & 15 & Gate $40 \mathrm{~cm}$ & 15 & 772 & 270 & lined \\
\hline
\end{tabular}




\subsubsection{Lined open canal}

A rectangular weir was used to measure the rate of flow of lined open canal, where the sides of the weir are actually the sides of the channel, it is called a suppressed rectangular weir. The rate of flow passing a point in lined open canal was estimated by applying the following formula:

$\mathrm{Q}=0.0184 . \mathrm{L} \cdot \mathrm{H}^{3 / 2}$

Where;

Q: The discharge over the Weir $(1 / \mathrm{s})$

$\mathrm{L}$ : The length of weir $(\mathrm{cm})$

$\mathrm{H}$ : The high of water on the weir $(\mathrm{cm})$

\subsubsection{Buried pipe}

The discharge from buried pipe was measured using Trajectory method. In this method the rate of flow is obtained by coordinate determination of any point of flow under operating condition, the flow at the outlet of pipe should be full. pipe may be horizontal or vertically just above the jet. In this flowing condition the pipes were vertically. The inside diameter "D" of the pipe was measured. Based on experimental work, Bos (1989), present to the following semi-empirical relationship:

$\mathrm{q}=3.48 . \mathrm{d}^{2} . \Delta \mathrm{h}^{0.5} \quad$ most accurate for $\Delta \mathrm{h}>1.4 \mathrm{~d}$

Where:

q: discharge $\left(\mathrm{m}^{3} / \mathrm{s}\right)$

$\mathrm{d}$ : inside diameter $(\mathrm{m})$

$\mathrm{h}$ : head of water $(\mathrm{m})$

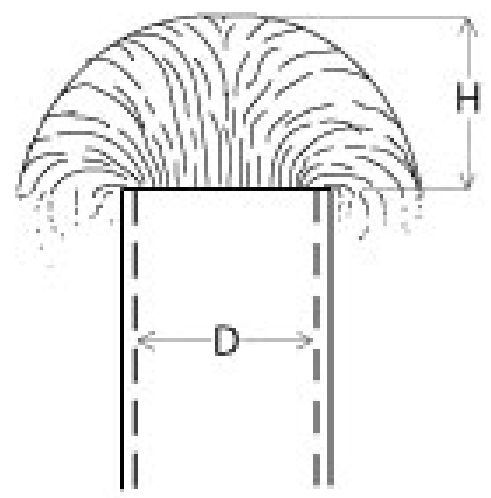

Fig. 1. Trajectory vertically method 


\subsubsection{Determination of water losses}

The conveyance loss was measured using the inflow-outflow method, which involves measurement the rate of water flows at water course test section and the rate of water flows out of it. estimation of Conveyance losses is essential to make decisions while designing an irrigation channel or allocating water supplies at the head of canal. Inflow-Outflow method has been used as bench mark method Sarki et al.,( 2008). In this method, actual discharges are measured between two selected points on canals. in order to estimate water losses and conveyance efficiency in unlined canal, lined canal and buried pipe. in three water distribution, earthen channel volume of water (inflow and outflow) was measured by the velocity-area method in lined channel. Two rectangular weirs were installed at sections A, B Thus the difference of discharges at section A and B gave conveyance losses in the lined canal. The Conveyance losses were estimated by following formula:

$\mathbf{C L}=\frac{\left(\boldsymbol{Q}_{\text {in }}-\boldsymbol{Q}_{\text {out }}\right)}{\operatorname{Qin}} \times \mathbf{1 0 0}$

Where:

$\mathrm{C}_{\mathrm{L}}=$ Conveyance losses $(\%)$

$\mathrm{Q}_{\text {in }}=$ Inflow rate $\left(\mathrm{m}^{3} / \mathrm{h}\right)$

$\mathrm{Q}_{\text {out }}=$ Out flow rate $\left(\mathrm{m}^{3} / \mathrm{h}\right)$

2.2.3. Financial analysisThe Financial analysis includes crop yield, cost of pumping, annual costs and benefits and the cost of structures. The data about crop yield, cost of pumping, annual costs and benefits from the field survey were carried out through questionnaire from the farmers in the experimental area. The data recorded on recall basis comprise of the area under main crops by each farmer before and after the development of canals for the crop season 2014-2015. The data was collected by interviewing the landowners located on the head, middle and tail reach of sample watercourse according to the plan made for the comparison of the events reach wise before and after development, the interviews were conducted with all types of land owners from small to large area.

2.2.3.1. Pumping cost The cost of pumping per year for Abdel-Mawgoud station before development includes different items such as cost of fuel and oil, maintenance and clean Merwa. After improvement, the pumping 
cost includes salary of the pump operator and guard, cost of energy, maintenance and clean of Merwa. The cost of pumping wear calculated as shown in table (6) and (7).

2.2.3.2. The cost of structures The costs of lining for the life of lined potion of water courses have been collected from on farm irrigation development projects management unit - ministry of agriculture and land reclamation. The capital costs of structures for the Merwa which has $250 \mathrm{~m}$ length In the lined canal the cost of structures for the Merwa was identifying 119 L.E/m length, this includes cleaning the ground from the previous crop, concrete bases (length of Merwa - width $90 \mathrm{~cm}$ - thickness $8 \mathrm{~cm})$, Sides from red blocks $40 \mathrm{Cm}$ height, Cover the sides by cement and sand. the canal dimensions $(40 \mathrm{~cm} \times 40 \mathrm{~cm} \times 40 \mathrm{~cm})$. and $115 \mathrm{~L} . \mathrm{E}$ for iron gate $40 \mathrm{~cm} \times 40 \mathrm{~cm}$ that one gate per fed and in upvc buried pipes. cost of structures was identifying $50 \mathrm{~L} . \mathrm{E} / \mathrm{m}$ this include pipes $250 \mathrm{~mm}$ diameter, digging, recover the pipe, installation pips and pipes test in the field and 700 L.E for iron hydrant 6" riser $1 \mathrm{~m}$ P.V.C. pipe, $160 \mathrm{~mm}$ out diameter, concrete block and concrete cylinder or cover the hydrant, each $4200 \mathrm{~m}^{2}$ has one hydrant

\subsubsection{Annual costs and income}

The main costs, benefit and the net income earned from the irrigated area before and after development it includes the overall cost of production (L.E./fed) and overall net income received (L.E./fed). Thus, total annual profits were estimated Effect of development by lined canal or buried pipes on farmers' income.

\subsection{Statistical analysis}

An analysis of variance (ANOVA) was performed by considering the variables related with water distribution systems (earthen canals, lined canals and upvc buried pipes) and the variables related with wheat ,alfalfa, maize and rice yield to estimate the effect of irrigation conveyance systems development on water Conveyance efficiency $\left(\mathrm{E}_{\mathrm{C}}\right)$, Conveyance losses $\left(\mathrm{C}_{\mathrm{L}}\right.$, irrigation time, water saving, land saving ,crop yield, cropping intensity ,cost of pumping, using M-Stat, Statistical Graphics Corp. Fisher's least significant difference (LSD) test was used to determine the significant differences between average groups in the ANOVA 
Table 6. The pumping cost before improvement.

\begin{tabular}{llllllll}
\hline $\begin{array}{l}\text { Agric. } \\
\text { season }\end{array}$ & $\begin{array}{l}\text { Field area } \\
\text { (fed) }\end{array}$ & $\begin{array}{l}\text { number } \\
\text { pumps }\end{array}$ & $\begin{array}{l}\text { No. of } \\
\text { irrigation }\end{array}$ & $\begin{array}{l}\text { Fuel } \\
\text { consumption } \\
\text { cost } \\
\text { (LE) }\end{array}$ & $\begin{array}{l}\text { Oil } \\
\text { consumption } \\
\text { cost } \\
\text { (L.E) }\end{array}$ & $\begin{array}{l}\text { Clean } \\
\text { Merwa } \\
\text { (L.E) }\end{array}$ & $\begin{array}{l}\text { Maintenancr } \\
\text { (L.E) }\end{array}$ \\
\hline winter & 73 & 14 & 40 & 15768 & 1428 & 925 & 2800 \\
summer & 73 & 14 & 86 & 33901 & 2856 & 925 & 2800 \\
\hline
\end{tabular}

Table 7. The pumping cost after improvement

\begin{tabular}{llllllll}
\hline $\begin{array}{l}\text { Agric. } \\
\text { season }\end{array}$ & $\begin{array}{l}\text { Field area } \\
\text { (fed) }\end{array}$ & $\begin{array}{l}\text { Number } \\
\text { pumps }\end{array}$ & $\begin{array}{l}\text { No. of } \\
\text { irrigation }\end{array}$ & $\begin{array}{l}\text { Electricity } \\
\text { Cost } \\
\text { (L.E) }\end{array}$ & $\begin{array}{l}\text { Maintenance } \\
\text { (L.E) }\end{array}$ & $\begin{array}{l}\text { Cleaning of } \\
\text { Merwa } \\
\text { (L.E) }\end{array}$ & $\begin{array}{l}\text { Guarding } \\
\text { and } \\
\text { operation } \\
\text { (L.E) }\end{array}$ \\
\hline winter & 73 & 3 & 40 & 3000 & 150 & 925 & 6000 \\
summer & 73 & 3 & 86 & 4000 & 200 & 925 & 6000 \\
\hline
\end{tabular}




\section{RESULTS AND DISCUSSIONS \\ 3.1. Conveyance efficiency $\left(E_{C}\right)$}

The conveyance efficiencies under earthen canals were $59.6 \%$ and $65.1 \%$ in summer and winter seasons, respectively, while the conveyance efficiency was raised after improvement under lined canals and upvc buried pipes, respectively. The conveyance efficiencies under upvc buried pipes were higher than of those achieved under lined canals. The results reveal that the less conveyance efficiency in earthen canal was due to lack of proper maintenance of the earthen canal hence more seepage and leakage losses due to the presence of vegetation. There were a significantly differences between conveyance efficiencies under different types of Merwa, while there weren't a significantly differences between the both growing seasons for each Merwa type (Table 8).

Table 8. The conveyance efficiency of the three types of Merwa.

\begin{tabular}{lll}
\hline \multirow{2}{*}{ Type of Merwa } & \multicolumn{2}{l}{ Conveyance efficiency $(\%)$} \\
\cline { 2 - 3 } & Summer & Winter \\
\hline Earthen canal & $59.6 \mathrm{c}$ & $65.1 \mathrm{c}$ \\
Lined canal & $87.1 \mathrm{~b}$ & $92.2 \mathrm{~b}$ \\
Buried pipe & $98.7 \mathrm{a}$ & $98.7 \mathrm{a}$ \\
LSD & 5.457 & \\
\hline
\end{tabular}

Means followed by the different letter are significantly different from one another based on Duncan's protected LSD test at $\mathrm{P} \leq 0.05$.

These results were agreement with Anonymous, (2014), Rahman et al. (2011), andArshad and Ahmad (2011).

3.2. Conveyance losses( $\left.\mathbf{C}_{\mathbf{L}}\right)$ the average Conveyance losses was measured by inflow-outflow method in earthen canal, was $40.5 \%$ in summer season and $35.2 \%$ in winter season after development. The average Conveyance losses was $12.9 \%, 1.3 \%$ in summer season and $7.8 \%, 1.3 \%$ in winter season in lined canal and buried pipe respectively. Whereas there were higher in the earthen canal in both seasons it was due to lack of proper maintenance of the earthen canal hence more seepage, evaporation and leakage losses presence of vegetation. 
The conveyance losses were lower in the lined canal in both seasons than earthen canal This was due to irregular shapes throughout the length and poor maintenance of the field channels and they haven't lost their regular shapes after construction. buried pipe achieved the lowest conveyance losses in the both seasons and highest percentage of reduction in the annual losses it was $96.3 \%$ to $96.8 \%$ compared with $68.1 \%$ to $77.7 \%$ of reduction (Table 9).

There were a significantly differences between conveyance losses under different types of Merwas, while there weren't a significantly differences between the both growing seasons for each Merwa type.

The result is in conformity with the findings of Rahman et al., (2011). and Maniruzzaman et al. (2002),

\subsection{Water saving}

Improved canals were intended to eliminate the losses of water through their cross sections. Improvement the irrigation conveyance system in command area contributed to save some quantities of water The amounts of water that are lost from the earthen canal which were $35 \%$ to $40.4 \%$ and $27.2 \%$ to $27.5 \%$ are saved after the development by lined canal that saved due to reduction seepage and leakage losses presence of vegetation. The highest amount of saved water was achieved after development by upvc buried pipes it was $33.7 \%$ to $39.1 \%$ that due to additional reasons of reduction losses in lined canal was prevented all amount of water which lost by evaporation to use them positively in the present days and in the future. There were a significantly differences in water saving after development by lined canal and upvc buried pipes, while there weren't a significantly differences between the both growing seasons for each Merwa type (Table 9).

3.4. Irrigation time the irrigation time for field crops in command area before development in winter season was ranged from 4 to $5 \mathrm{~h} / \mathrm{fed}$, while in summer season it was $5 \mathrm{~h} / \mathrm{fed}$. After development, the irrigation time decreases to $2 \mathrm{~h} / \mathrm{fed}$ in winter season, while it decreases to $2.5 \mathrm{~h} / \mathrm{fed}$ in summer season (Fig. 3). The impact of improvement on decreasing irrigation time was ranged from $50 \%$ to $60 \%$ for the different field crops. 
Table 9. The conveyance losses and water saving.

\begin{tabular}{|c|c|c|c|c|c|c|}
\hline \multirow[t]{2}{*}{$\begin{array}{l}\text { Type of } \\
\text { Merwa }\end{array}$} & \multicolumn{2}{|c|}{$\begin{array}{l}\text { Conveyance } \\
\text { losses } \\
(\%)\end{array}$} & \multicolumn{2}{|c|}{$\begin{array}{l}\text { Water saving } \\
(\%)\end{array}$} & \multicolumn{2}{|c|}{$\begin{array}{l}\text { Development impact on } \\
\text { reducing } \\
\text { losses }(\%)\end{array}$} \\
\hline & Summer & Winter & Summer & Winter & Summer & Winter \\
\hline $\begin{array}{l}\text { Earthen } \\
\text { canal }\end{array}$ & $40.4 \mathrm{a}$ & $35.0 \mathrm{a}$ & - & - & - & - \\
\hline $\begin{array}{l}\text { Lined } \\
\text { canal }\end{array}$ & $12.9 \mathrm{~b}$ & $7.8 \mathrm{~b}$ & $27.5 b$ & $27.2 b$ & 68.1 & 77.7 \\
\hline $\begin{array}{l}\text { Buried } \\
\text { pipe }\end{array}$ & $1.3 \mathrm{c}$ & $1.3 \mathrm{c}$ & $39.1 \mathrm{a}$ & $33.7 \mathrm{a}$ & 96.8 & 96.3 \\
\hline LSD & 5.457 & & 5.476 & & & \\
\hline
\end{tabular}

Means followed by different letters for conveyance losses are significantly different from one another based on Duncan's protected LSD test at $\mathrm{P} \leq 0.05$. and the Means followed by different letters for saved water are significantly different from one another based on Duncan's protected LSD test at $\mathrm{P} \leq 0.05$.

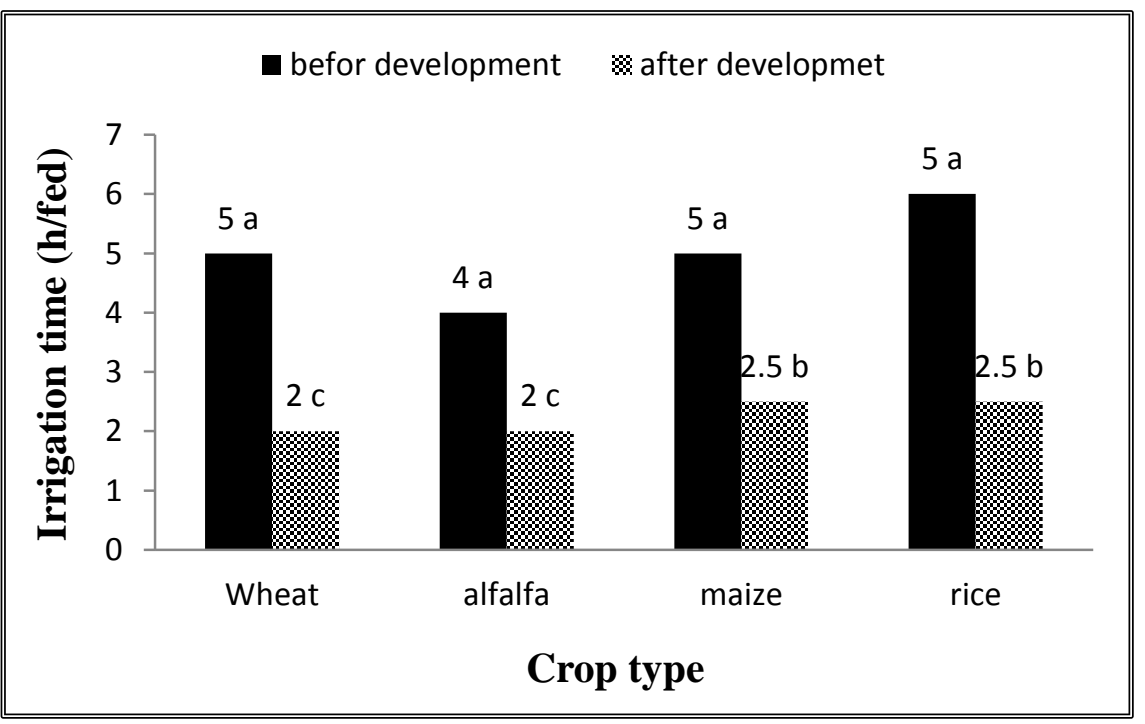

Bars shown with different letters are significantly different at the 0.05 probability level for irrigation time and crop type and least significant difference (LSD) for irrigation time under different crop types equals 0.1883 .

Fig. 3. Impact of improvement on decreasing irrigation time.

This decrement of irrigation time is due to irregular irrigation time among the farmers in improved Merwas and single lifting point. Improvement process made water available all the time in the Mesqa, better scheduling 
of irrigation and higher flow rate at the field level has also contributed to reduce the irrigation time.

There were a significantly differences for irrigation time after development of Merwa and there were a significantly differences between the both growing seasons for upvc buried pipes ad lined canal (Fig. 3). These results were agreement with Kotb and Boissevain (2013).

\subsection{The impact of development on agricultural area}

There was a positive influence of development on agricultural area, where there was an increment of agricultural area by $34 \mathrm{~m}^{2} /$ fed and 59 $\mathrm{m}^{2} /$ fed under lined canal and upvc buried pipes, respectively. It may be noted that with the rise in the agricultural area there has been a concomitant increase in the crop yields of the land saving or land increase; which is a result of the construction of improved Merwas as compared to areas occupied by old Merwas. These benefits of land saving were about $0.8 \%$ of the total saved area after development by lined canal and $1.4 \%$ of the total command area saved after development by upvc buried pipes, it had become available for agriculture and roads (Table 10).

Table 10. The effect of development on command area

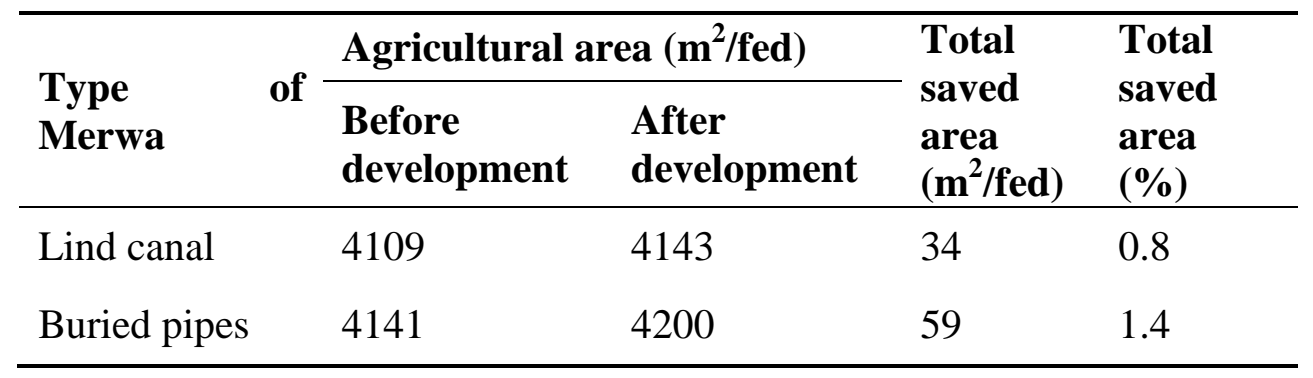

\subsection{Cropping intensity}

It is evident that annual cropping intensity before and after improvement were $195.66 \%$ and $197.28 \%$ under lined canal, respectively, while the cropping intensity before and before development under buried pips were $197.20 \%$ and $200 \%$, respectively. There was a positive impact of improvement on cropping intensity, where there was an increment of cropping intensity by $1.6 \%$ and $2.8 \%$ under lined canal and upvc buried pipes, respectively (Table 11). 
Table 11. The impact of development on cropping intensity.

\begin{tabular}{|c|c|c|c|c|c|c|c|}
\hline \multirow{3}{*}{$\begin{array}{l}\text { Type of } \\
\text { Merwa }\end{array}$} & \multicolumn{6}{|c|}{ Cropping intensity (\%) } & \multirow{3}{*}{$\begin{array}{l}\text { Incremen } \\
(\%)\end{array}$} \\
\hline & \multicolumn{2}{|c|}{ Winter } & \multicolumn{2}{|c|}{ Summer } & \multicolumn{2}{|l|}{ Annual } & \\
\hline & Before & After & Before & After & Before & After & \\
\hline $\begin{array}{l}\text { Lined } \\
\text { canal }\end{array}$ & 97.83 & 98.64 & 97.83 & 98.64 & 195.66 & 197.28 & 1.6 \\
\hline $\begin{array}{l}\text { Buried } \\
\text { pipes }\end{array}$ & 98.60 & 100 & 98.60 & 100 & 197.20 & 200 & 2.8 \\
\hline
\end{tabular}

\subsection{Crop yield}

The improvement process has an agricultural benefit like increment in crop yields due to the better conditions of water availability. Wheat had the lowest increment of crop yield among field crops by 16 to $30 \mathrm{~kg} / \mathrm{fed}$ under wheat for lined canal and upvc buried pipes, respectively, while the Alfalfa had the largest increment in crop yield by 290 to $510 \mathrm{~kg} / \mathrm{fed}$, for lined canal and upvc buried pipes, respectively. The yield increment as a percentage for all field crops were $0.8 \%$ and $1.4 \%$ for lined canal and upvc buried pipes, respectively (Table 12).

There were a non-significantly differences for crop yield between lined canal and upvc buried pipes, but there were a significantly differences between the both growing seasons for upvc buried pipes ad lined canal

Table 12. Impact of development on crop yield.

\begin{tabular}{lllll}
\hline \multirow{2}{*}{$\begin{array}{l}\text { Crop } \\
\text { type }\end{array}$} & \multicolumn{2}{l}{ Yield increment $(\mathbf{K g})$} & \multicolumn{2}{c}{ Yield increment $(\%)$} \\
\cline { 2 - 5 } & Lined canal & Buried pipes & Lined canal & Buried pipes \\
\hline Wheat & $16 \mathrm{a}$ & $30 \mathrm{a}$ & 0.8 & 1.4 \\
Alfalfa & $290 \mathrm{a}$ & $510 \mathrm{a}$ & 0.8 & 1.4 \\
Maize & $21 \mathrm{~b}$ & $37 \mathrm{~b}$ & 0.8 & 1.4 \\
Rice & $28.3 \mathrm{~b}$ & $49.2 \mathrm{~b}$ & 0.8 & 1.4 \\
LSD & 340.9 & 730.2 & & \\
\hline
\end{tabular}

\subsection{Financial analysis}

\subsubsection{Pumping cost}

The cost of pumping for Abdel-Mawgoud station before development was 554 L.E in summer season and 287L.E in winter season, after improvement the pumping cost was decreasing to be 138L.E in winter and 153L.E in summer (Fig. 4). Lower pumping costs due to a decrease 
or absence of many of the items used to calculate the pumping costs, such as; the absence of fuel and oil costs that used to run the diesel pumps to be replaced by electrical pumps, reduce the number of pumps used from 14 diesel pumps with multi lifting points to 3 electrical pumps with a single lifting point, get rid of the high maintenance costs of pumps that operate by diesel as well as special clean specular weeds and sludge accumulated maintenance costs at the bottom of irrigated canals and that has helped farmers in best scheduling of irrigation water, which reflected in turn, reduce production costs and increase profits.

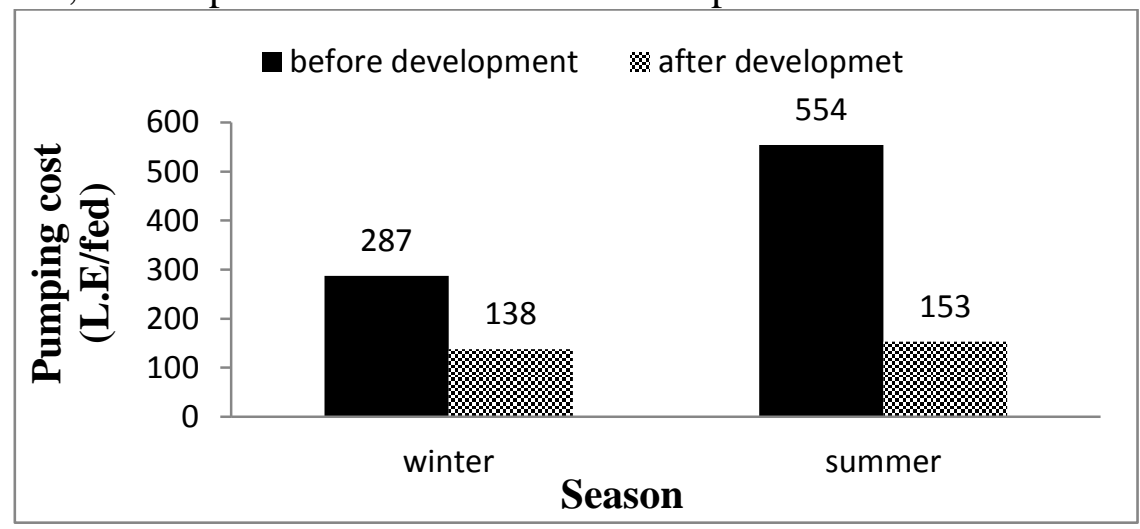

Fig. 4. The pumping cost in growing seasons.

\subsubsection{Cost of structures}

The cost of structures for improvement by lining was high and need to be reduced. The costs of construction of the open elevated and upvc buried pipes were 3833.75 L.E./fed and 2887.5 L.E./fed, respectively, it was cleared that the cost of structures for upvc buried pipes less than lined canal by about 950 L.E./fed (Table 13). The result is in conformity with Javaid, et al. (2012

Table 13. The cost of structures for Merwas.

\begin{tabular}{llllllll}
\hline $\begin{array}{l}\text { Merwa } \\
\text { type }\end{array}$ & $\begin{array}{l}\text { Merwa } \\
\text { length } \\
(\mathbf{m})\end{array}$ & $\begin{array}{l}\text { Serviced } \\
\text { area } \\
\text { (fed) }\end{array}$ & $\begin{array}{l}\text { Cost of } \\
\text { Structure } \\
\text { (L.E./m) }\end{array}$ & $\begin{array}{l}\text { Offtake } \\
\text { type }\end{array}$ & $\begin{array}{l}\text { Offtake } \\
\text { cost } \\
\text { (L.E.) }\end{array}$ & $\begin{array}{l}\text { Total } \\
\text { cost } \\
\text { (L.E.) }\end{array}$ & $\begin{array}{l}\text { Cost } \\
\text { (L.E./fed) }\end{array}$ \\
\hline $\begin{array}{l}\text { Lined } \\
\text { canal }\end{array}$ & 250 & 8 & 119 & Gate & 115 & 30670 & 3833.75 \\
$\begin{array}{l}\text { Buried } \\
\text { pipe }\end{array}$ & 250 & 8 & 70 & hydrant & 700 & 23100 & 2887.5 \\
\hline
\end{tabular}




\subsubsection{Annual costs and income}

As discussed before the yield increment as a percentage for all field crops were $0.8 \%$ and $1.4 \%$ for lined canal and buried pipes, respectively (Table 14 and 15). The highest profit as a percent was obtained under maize, for both lined canal and buried pipes, respectively, while the lowest profit was recorded under wheat for both lined canal and buried pipes, respectively.

Table 14. Effect of development by lined canal on farmers' income.

\begin{tabular}{|c|c|c|c|c|c|}
\hline $\begin{array}{l}\text { Crop } \\
\text { type }\end{array}$ & $\begin{array}{l}\text { Evaluation } \\
\text { parameters }\end{array}$ & $\begin{array}{l}\text { Earthen } \\
\text { canal }\end{array}$ & $\begin{array}{l}\text { Lined } \\
\text { canal }\end{array}$ & impact & $\begin{array}{l}\text { Percentage } \\
(\%)\end{array}$ \\
\hline \multirow[t]{5}{*}{ Wheat } & Cultivated area $\left(\mathrm{m}^{2}\right)$ & 4109 & 4143 & +34 & 0.8 \\
\hline & Yield (Kg) & 2132 & 2148 & +16 & 0.8 \\
\hline & Product cost (L.E.) & 2910 & 2735 & -175 & 6.0 \\
\hline & Income (L.E.) & 5880 & 5920 & +40 & 0.7 \\
\hline & Profit (L.E.) & 2970 & 3185 & +215 & 7.2 \\
\hline \multirow[t]{5}{*}{ Alfalfa } & Cultivated area $\left(\mathrm{m}^{2}\right)$ & 4109 & 4143 & +34 & 0.8 \\
\hline & Yield $(\mathrm{Kg})$ & 29744 & 29984 & +240 & 0.8 \\
\hline & Product cost (L.E.) & 1980 & 1755 & -225 & 11.4 \\
\hline & Income (L.E.) & 3161 & 3186 & +25 & 0.8 \\
\hline & Profit (L.E.) & 1181 & 1431 & +250 & 21.2 \\
\hline \multirow[t]{5}{*}{ Maize } & Cultivated area $\left(\mathrm{m}^{2}\right)$ & 4109 & 4143 & +34 & 0.8 \\
\hline & Yield (Kg) & 2603 & 2624 & +21 & 0.8 \\
\hline & Product cost (L.E.) & 2800 & 2575 & -225 & 8.0 \\
\hline & Income (L.E.) & 3718 & 3748 & +30 & 0.8 \\
\hline & Profit (L.E.) & 918 & 1173 & +255 & 27.8 \\
\hline \multirow[t]{5}{*}{ Rice } & Cultivated area $\left(\mathrm{m}^{2}\right)$ & 4109 & 4143 & +34 & 0.8 \\
\hline & Yield (Kg) & 3424.2 & 3452.5 & +28.3 & 0.8 \\
\hline & Product cost (L.E.) & 4100 & 3775 & -325 & 7.9 \\
\hline & Income (L.E.) & 6120 & 6210 & +90 & 1.5 \\
\hline & Profit (L.E.) & 2020 & 2435 & +415 & 20.5 \\
\hline
\end{tabular}


Finally, all the results presented before indicated that improving conveyance efficiency by using buried pipes gave highest values for cultivated area for all crops and highly net profit, in addition this means that buried pipes will be the key for successful irrigation management.

Table 15. Effect of development by buried pipes on farmers' income.

\begin{tabular}{|c|c|c|c|c|c|}
\hline $\begin{array}{l}\text { Crop } \\
\text { type }\end{array}$ & $\begin{array}{l}\text { Evaluation } \\
\text { parameters }\end{array}$ & $\begin{array}{l}\text { Earthen } \\
\text { canal }\end{array}$ & $\begin{array}{l}\text { Buried } \\
\text { pipes }\end{array}$ & impact & $\begin{array}{l}\text { Percentage } \\
(\%)\end{array}$ \\
\hline \multirow[t]{5}{*}{ Wheat } & Cultivated area $\left(\mathrm{m}^{2}\right)$ & 4141 & 4200 & +59 & 1.4 \\
\hline & Yield $(\mathrm{Kg})$ & 2145 & 2175 & +30 & 1.4 \\
\hline & Product cost (L.E.) & 2910 & 2715 & -195 & 6.7 \\
\hline & Income (L.E.) & 5916 & 6000 & +84 & 1.4 \\
\hline & Profit (L.E.) & 3006 & 3285 & +279 & 9.3 \\
\hline \multirow[t]{5}{*}{ Alfalfa } & Cultivated area $\left(\mathrm{m}^{2}\right)$ & 4141 & 4200 & +59 & 1.4 \\
\hline & Yield $(\mathrm{Kg})$ & 29968 & 30400 & +432 & 1.4 \\
\hline & Product cost (L.E.) & 1980 & 1730 & -250 & 12.6 \\
\hline & Income (L.E.) & 3185 & 3230 & +45 & 1.4 \\
\hline & Profit (L.E.) & 1205 & 1500 & +295 & 24.5 \\
\hline \multirow[t]{5}{*}{ Maize } & Cultivated area $\left(\mathrm{m}^{2}\right)$ & 4141 & 4200 & +59 & 1.4 \\
\hline & Yield $(\mathrm{Kg})$ & 2623 & 2660 & +37 & 1.4 \\
\hline & Product cost (L.E.) & 2800 & 2550 & -250 & 8.9 \\
\hline & Income (L.E.) & 3746 & 3800 & +54 & 1.4 \\
\hline & Profit (L.E.) & 946 & 1250 & +304 & 32.1 \\
\hline \multirow[t]{5}{*}{ Rice } & Cultivated area $\left(\mathrm{m}^{2}\right)$ & 4141 & 4200 & +59 & 1.4 \\
\hline & Yield $(\mathrm{Kg})$ & 3450.8 & 3500 & +49.2 & 1.4 \\
\hline & Product cost (L.E.) & 4100 & 3750 & -350 & 8.5 \\
\hline & Income (L.E.) & 6228 & 6300 & +72 & 1.2 \\
\hline & Profit (L.E.) & 2128 & 2550 & +422 & 19.8 \\
\hline
\end{tabular}




\section{CONCLUSIONS}

\section{The main conclusions of this research can be proposed as follows:}

$\checkmark$ The increasing of the inflow discharge to the area under study can be achieved through optimizing use of the available quantities of Nile water belongs to the study area, at the same time, the increasing of the inflow discharge to the study area can be achieved through minimizing the losses of water by seepage, percolation and evaporation.

$\checkmark$ The results presented before indicated that improving conveyance efficiency by using upvc buried pipes gave highest values for cultivated area for all crops, in addition this means that upvc buried pipes will be the key for successful irrigation management under Egyptian conditions.

$\checkmark$ Fairness of water distribution along Mesqas improved to about $97 \%$.

$\checkmark$ Land saving: There is about $1 \%$ of the total command area has been saved and made available for agriculture and roads.

$\checkmark$ The use of upvc buried pipes has a special clean specular weeds and sludge accumulated maintenance costs at the bottom of irrigated canals and that has helped farmers in best scheduling of irrigation water, which reflected in turn, reduce production costs and increase profits.

$\checkmark$ The applying of single lifting point and electrical pumps will achieve many advantages including; decreasing pumping costs, reducing the number of pumps used from 14 diesel pumps to 3 electrical pumps, get rid of the high maintenance costs of pumps that operate by diesel.

\section{REFERENCES}

Akbar, S., Abbas, A., Hanjra, M.A. and Khan S. (2013). Structured analysis of seepage losses in irrigation supply channels for costeffective investments: case studies from the southern Murray Darling Basin of Australia. Irrigation Science, vol. 31(1): 11-25.

Ali, M. H. (2011). Water Conveyance Loss and Designing Conveyance System.

Anonymous, (2014). Water Resources. State of the environment report. India International Journal of Innovative Research in Science, Engineering and Technology. 3, Special Issue 4.

Arshad, M. and N. Ahmad. (2011). Performance assessment of irrigation system in rice and wheat cropping zone using modern techniques. ICID 21st International Congress on Irrigation and Drainage, 15-23 October 2011, Tehran,Iran 
Bos, M. G.. (1989). Discharge Measurement Structures. Publication 20, International Institute for Land Reclamation and Improvement, Wageningen, The Netherlands, (3rd revised edition).

El-Kassar, G.M. (2007). Monitoring and Evaluation of Improved Irrigation Delivery System in W/10 Command Area, Egypt. Science Water Journal-NWRC-December.

FAO Aquastat. (2008).

Hvidt, M. (1998). Water, technology, and development: Upgrading Egypt's irrigation system. London: Tauris Academic Studies.

Ibrahim, M.A. (2003). Some Aspects towards On-Farm Effective Irrigation Management", Proc. of 7th Int. Water Technology Conf., Egypt.

INCID (1998). Pipe Distribution System for Irrigation. Indian National Committee on Irrigation and Drainage, New Delhi.

James, G. L., (1988): Principles of farm irrigation system design.John Wiley and Sons, Inc.( 85- 105 ): 543PP.

Javaid, F., Arshad, M., Azam, M., Shabbir, A. and Shakoor, A. (2012). Performance assessment of lined watercourses in district Jhang. Pak. J. Agri. Sci. 49(1):79-83

Kotb, T. and Boissevain, W. (2012). Water Saving Due to Irrigation Improvement in the Nile Delta. Lamaddalena N., Lebdi F., Todorovic M., Bogliotti C., Irrigation systems performance. CIHEAM, Bari, Pp. 85-98.

M. A. Sayed, (2014). "Impact of Lined Canals on Shallow Tube well Irrigation and Their Acceptability by the Farmers". Institute of Water and Flood Management, BUET,. International Journal of Innovative Science, Engineering \& Technology, Vol. 1 Issue 10,

Memon, A. A., K.Q. Leghari, A. F. H. Pathan, K. L. Khatri, S. A. Shah, K. K.Pinjani, R. Soomro and K. Ansari. (2013). Design and evaluation of Dadu canal lining for sustainable water saving. J. Water Reso.Protection. 5:689-98

M. Maniruzzaman, M. M. Alam, F. I. M. G. W. Sarkar, M. T. Islam, M. N. Islam. (2002). "Water Saving Techniques through Improved Water Distribution System in Deep Tubewell Area of Bangladesh", Paper published in Online Journal of Biological Sciences 2 (3), , pp: 178-182. 
Rahman, M., A. H. M. Kamal, A. A. Mamun and S. U. Miah. 2011. Study on the irrigation water distribution system developed by barind multipurpose development authority. Journal of Bangladesh Association of Young Resarchers 1(2):63-71

Sahu, P., Saxena, A. K., \& Travadi, M. K. (2014). The Use of Canal Lining Available materials and Its Comparative Study".IOSR Journal of Mechanical and Civil Engineering11 (3): 81-86

Sarki, A., Memon, S. Q and Leghari, M. 2008. Comparison of Different Methods for Computing Seepage Losses in an Earthen Watercourse. J. Agric, Tropica Et. Subtropica, 41 (4): 197-205.

Schwab, G.O., Fangmeier, D.D., Elliot, W.J. and Frevert, R.K. (1993). Soil and Water Conservation Engineering Fourth Edition. John Wiley \& Sons, Inc. New York.

الملخص العربيى

تحسين كفاءة نقل وتوزيع مياه الري باستخدام القتوات المبطنة والأنابيب

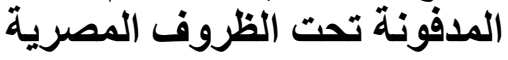

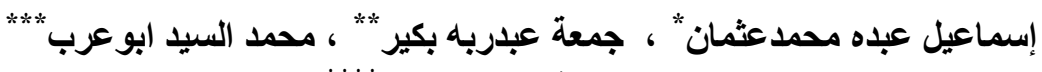
و مجدي توفيق الطنطاوي

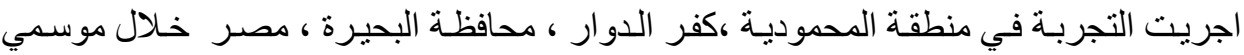

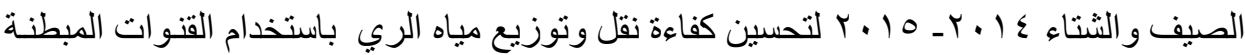

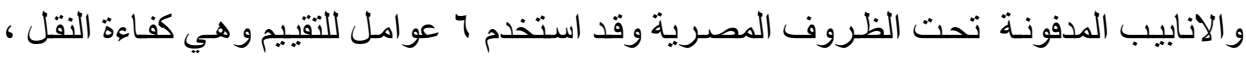
توفير المياه ، زمن الري ، توفير الارض كو الكثافة المحصولية ، انتاجية المحاصيل ، و التحليل

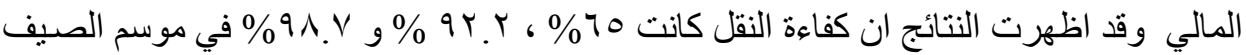

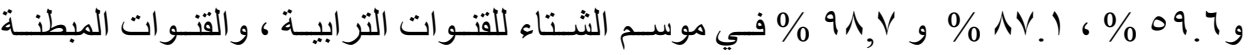

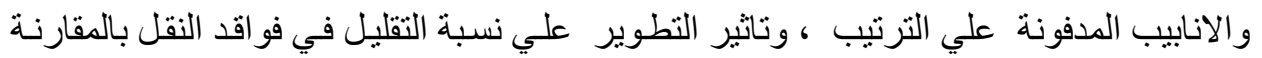

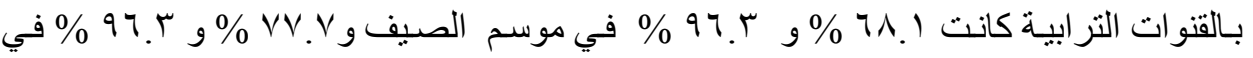

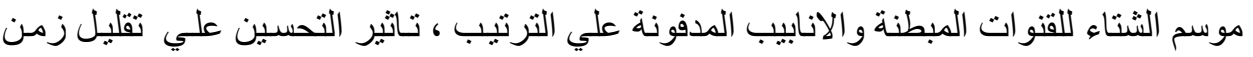

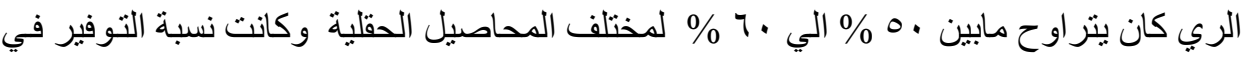

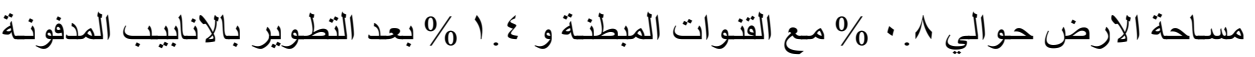

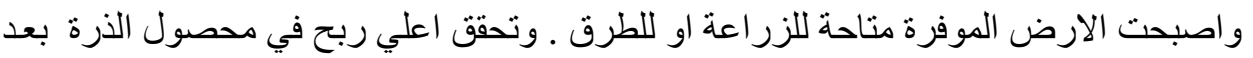

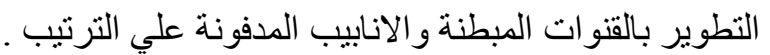

* بكالوريوس علوم زراعية ـ معهل بحوث الهندسة الزراعية.

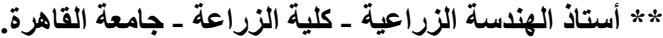

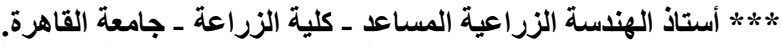

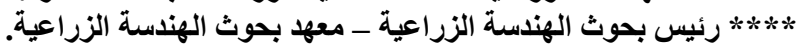

